\title{
LEARNING SCALES REPRESENTED IN GRAPHICS: AN INTERVENTION STUDY
}

\author{
Betânia Evangelista and Gilda Guimarães \\ Federal University of Pernambuco, Brazil \\ gilda.lguimaraes@gmail.com
}

This research aimed to investigate the influence of an educational intervention with scales represented in bar charts and lines, with 69 primary school 5th grade students (10 years old) with three types of activities that explored the scale concept : length measures (MC), number of lines $(R N)$ and maps (MP). During the intervention, we sought to generate discussion about the unity of the scale and the existing proportionality within. The results revealed that after only two intervention sessions, the students in all groups had a significant advancement. Although the activities required different contexts, a particular type of solution strategy for each one was not found. Thus, it would be safe to affirm that if students are to become critical readers and producers of information in graphics, they will need to be given a systematic work in schools.

The great need for discussing issues which require statistics is evident, especially in the realm of education, and by the continual search for statistical data in our day-to-day endeavours. Therefore, reading, interpreting and inference drawing from graphs, tables, so on and so forth turn out to be an important aspect in the subject matter.

As Ponte, Brocardo and Oliveira (2009) have stated, statistics plays an important role in education. It is regarded as an important tool for carrying out projects and research in various fields, and it is also used in planning, data collection and analysis; in decision making based on achievements; used to support statements in assorted areas, such as health, education, science and politics.

Therefore, Lopes (2008) argues that statistical concepts need to be addressed at the earliest years of schooling, so that students may acquire a broader understanding of the world problems they live in When confronted with a number of problem situations throughout their lives, students will be empowered to make the best choices in finding strategies to solve whatever problems come their way, which may go a long way in helping them develop their thinking process.

However, research (Guimarães, 2002; 2009; Lima, 2005 Albuquerque, 2010; Silva, 2012) has shown the difficulty students face to understand scales displayed in graphics. This should be of concern since the scales are paramount when it comes to graphics.

Understanding how scales work is thought to be an essential tool in grasping the information provided in graphs. By analysing graphics presented in the press, Cavalcanti, Natrielli and Guimarães (2010) found that 39\% of those graphs presented proportionally inadequate scales, which can mislead readers to misunderstanding the actual information the news report was intended to produce at first.

As far as Guimarães (2002) is concerned, students lack the understanding that there is continuity in the numerical ranges of a scale, and so they face a great deal of difficulties establishing proportionality between the values of a scale. And these cause them to underscore the need for a systematic and inter-related work, which may help them to reflect on the importance and functionality of the use of scales, as well as understand the importance of length, and also empower them to discuss measurement units and their subunits.

Furthermore, scales permeate various mathematical contents, such as proportionality, reading maps and charts, length, construction of figures and so on. These various forms of scales use show an important articulator function both in mathematics, and other areas of knowledge such as Geography, Cartography, Engineering, to name a few. The National Curriculum Standards for Mathematics - PCN (Brazil, 1997), spouses the grasping of scales to be developed for all content blocks (number and operations, space and form, measurements, statistic), in this way enabling connection between such contents. Contrary to fact, however, the scale concept is hardly ever exploited systematically and with intent, as argued by Melo and Bellemain (2004).

In: M.A. Sorto (Ed.), Advances in statistics education: developments, experiences and assessments. Proceedings of the Satellite conference of the International Association for Statistical Education (IASE), July 2015, Rio de Janeiro, Brazil. 
According to Albuquerque (2010) and Silva (2012) the difficulties students in different school grades face dealing with scales are evident both in the activities that require mastering of the ability to interpret graphs and in building, particularly when the values to be worked with are not explicit. More often than not students are able to glean snatches of information from the scale, but invariably they have little idea as to how to choose an appropriate scale to represent a set of data.

In this context, this research has investigated the contributions from an educational intervention on scales represented in bar graphs and lines, with 5th grade students from a primary school with three types of interventional situations, which addressed the scale concept: length measures, number of lines and maps.

\section{METHODOLOGY}

This research was carried out in three different public schools in the Metropolitan area of Recife - Brazil. The study included 695 th grade students from a primary school in three classrooms. Data collection occurred in three distinct stages with students attending the normal classes' period. First, an 8-question individual test was offered to assess students' knowledge on scales represented in bar and line charts. The issues involving skills to represent or to find values in the scale disclose errors on the scale to correspond representations in graphs and tables and build a chart from a table. (see the question on the results)

Second, an educational intervention was carried out. The activities developed for these interventions stemmed from contexts found by Evangelista and Guimarães (2013) when they were analysing Mathematics textbooks for 4th and 5th graders of primary schools in Brazil. Each of the three classes participated in one of these types of contexts: measures length (MC), number line (RN) and maps (MP). Two sessions of approximately an hour and a half, dealt with activities involving interpretation and construction of scales bearing these contexts. When teaching intervention skills representation, location, analysis, comparison and construction of scales with different intervals were exploited. In these classes, students were asked to solve the issues in pairs, and then the whole class discussed their responses under the coordination of a researcher/teacher. When reflecting on the activities of correction it was sought to work with the values shown in the scale and their subdivisions. (i.e.: enter the numbers 10 and 20 and what values will you get? This number is close to the value 30 . That number can be?...). We decided to use the teaching intervention, taking into consideration three types of situations. It involved no direct representation in graphics, the purpose was just to investigate the possibility of these activities, usually proposed in textbooks, contribute in learning and interpreting scales in bar and line graphics.

Finally, in the third stage a post-test similar to the pre-test (8 individual questions) was carried out to assess the possible contribution of the intervention in the learning process of scales.

\section{RESULTS}

The three groups showed no significant differences in the pre-test $[F(2,68)=1,285 ; p=$ .283]. As it can be seen in Figure 1, the three groups had great difficulty in the pre-test. However, after the intervention, all groups advanced significantly. According to the T-test paired sample, the performance difference was significant for all groups: MC group [ $\mathrm{t}(23)=-$ $4.143 ; \mathrm{p} \leq .000]$, the RN group [t $(22)=-7.497 ; \mathrm{p} \leq .000]$ and MP group [ $\mathrm{t}(21)=-3.813 ; \mathrm{p}$ $<.001]$. 


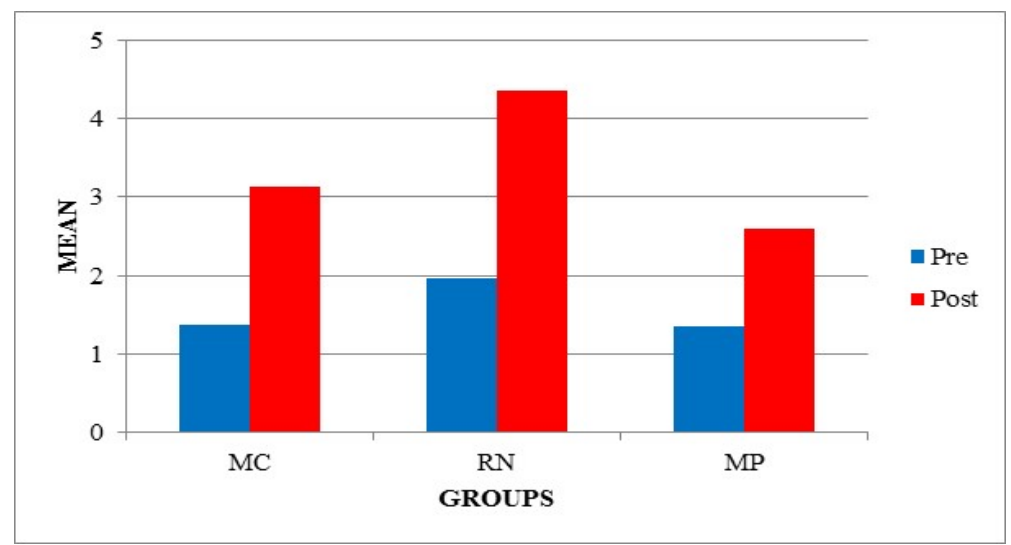

Figure 1: Average scores in tests by group and phase

Thus, the intervention performed with each group contributed effectively in the learning process of charts represented in scales, regardless the situation the teaching intervention is involved in. These results seem to be indicative of the ease with which children learn how to grasp information from scales provided they receive systematic stimulation.

Once the study general data has been presented, the importance of a systematic teaching ascertained and the understanding of scales in charts by fifth grade students is proven feasible (kids at the age of ten or thereabouts), we now present the specific results and resolution examples. Table 1 shows in detail the percentage of correct answers obtained by each group according to each question explored in phases (pre-test and post-test).

Table 1: Percentage of correct answer per group, per issue and per phase

\begin{tabular}{l|c|c|c|c|c|c}
\hline \multicolumn{1}{c}{$\begin{array}{c}\text { Groups / } \\
\text { Questions }\end{array}$} & \multicolumn{2}{c|}{$M C$} & \multicolumn{2}{c|}{$R N$} & \multicolumn{2}{c}{$M P$} \\
\cline { 2 - 8 } & Pre & Post & Pre & Post & Pre & Post \\
\hline $1^{\text {a }}$ - Represent values in the scale in a bar graph & 12.5 & 45.8 & 34.8 & 56.5 & 13.6 & 31.8 \\
\hline $2^{\text {a }}$ - Represent values in the scale in a line graph & 12.5 & 41.7 & 21.7 & 65.2 & 13.6 & 31.8 \\
\hline $3^{\text {a }}$ - Find values in the scale of a bar graph & 8.3 & 58.3 & 8.7 & 52.2 & 9.1 & 27.3 \\
\hline $4^{\text {a }}$ - Find values in the scale of a line graph & 12.5 & 29.2 & 17.4 & 43.5 & 9.1 & 13.6 \\
\hline $5^{\text {a }}$ - Identify wrong values in a scale bar graph & 8.3 & 20.8 & 26.1 & 52.2 & 27.3 & 54.5 \\
\hline $6^{\text {a }}$ - Represent the data from a chart in a table & 50.0 & 45.8 & 65.2 & 78.3 & 54.5 & 63.6 \\
\hline $7^{\text {a }}$ - Compare the same data presented in graphs with \\
different scales
\end{tabular}

It can be seen in Table 1 that all groups performed better in the post-test on all issues. These results show that the intervention, i.e. the two classes taught on scales represented in graphs by the researcher/teacher were effective for all groups and covered different skills.

In the pre-test, a very common type of answer was to copy the values of the statement or the scale (Figure 1). In Figure 2, there is an example often used by students which represents the values in ascending order, but without providing proportionality. 


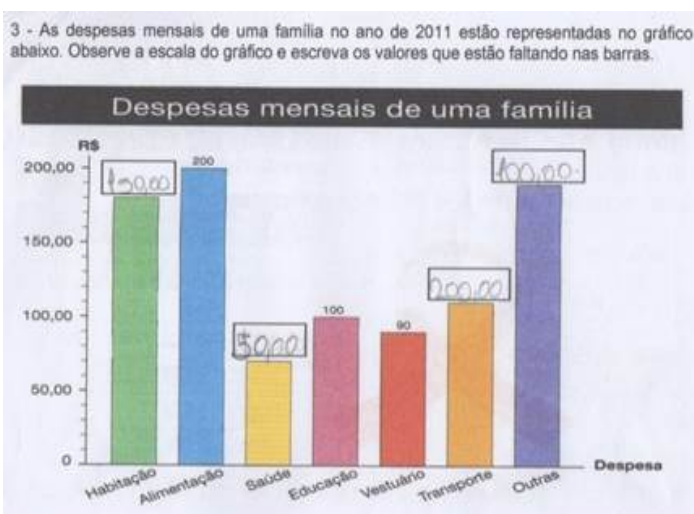

Figure 1: Example of responses that used values presented in the scale (questions 3 and 4).

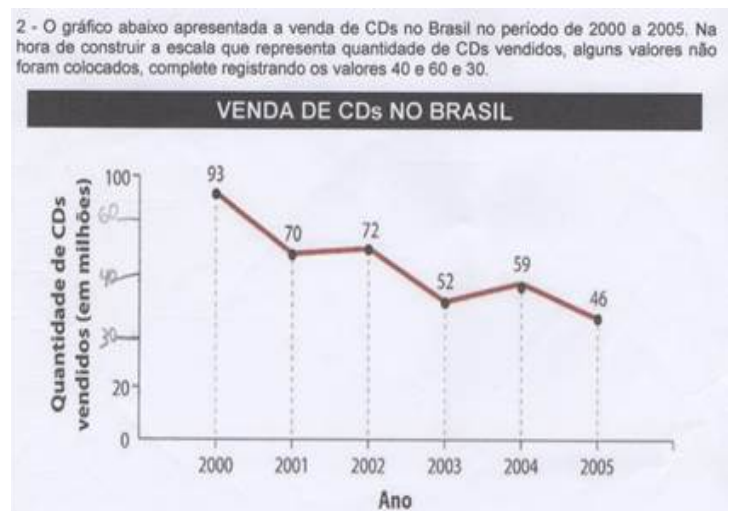

Figure 2: Example of responses represented the values in ascending order, but without providing proportionality (questions 1 and 2).

Guimarães (2002; 2009), Bruno and Espinal (2005), Lima (2005) and Albuquerque (2010) observed in their studies that finding incorrect values on the scale or represent values are skills that students of different grades find it quite difficult to perform. These authors argue that this flaw may be related to the difficulty understanding the continuous values presented in a number line, and the need to establish proportionality between points.

Learning can be attained by way of analyzing errors (Figure 3). During the intervention that point was constant object of reflection with the students. This result can also be observed in performance improvement in the $5^{\text {th }}$ question specifically. In the $6^{\text {th }}$ question students performed well in the pre-test (Figure 4) and continued performing well in post-test.

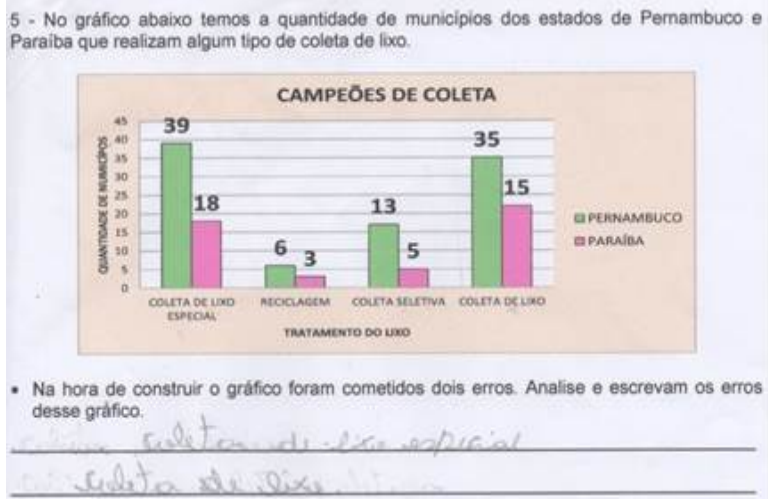

Figure 3: Example of response for the ability to locate errors in the scale in the values expressed in the graph bars (question 5).

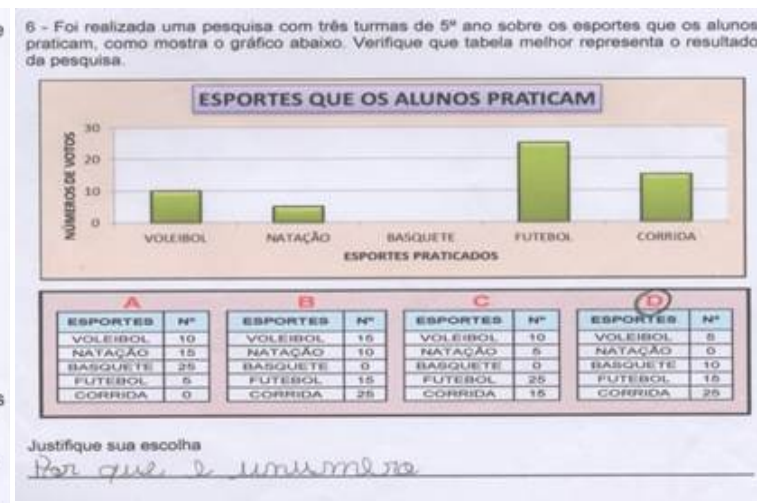

Figure 4: Example of response for the ability to match values expressed in a table graph (question 6).

On the other hand, all groups showed in both phases great difficulty with the 7th issue. The students were not able to realize that the difference between the two graphs was to break the difference of the scales (Figure 5). We note that while the participant has opted for graph 1, he or she did not offer a coherent justification "as to why that was the right answer." This question, in fact, was also considered very difficult for children and adults, who participated in the study by Albuquerque (2010).

With the $8^{\text {th }}$ question, which involved constructing a graph from a table, most students had difficulty putting values on the top of the bars but none with proportionality. 


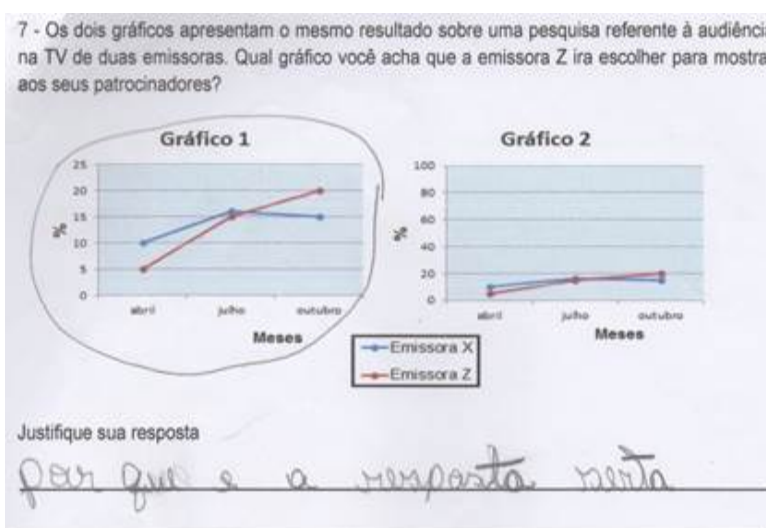

Figure 5: Example of response for the ability to compare the same data presented in graphs with different scales (question 7).

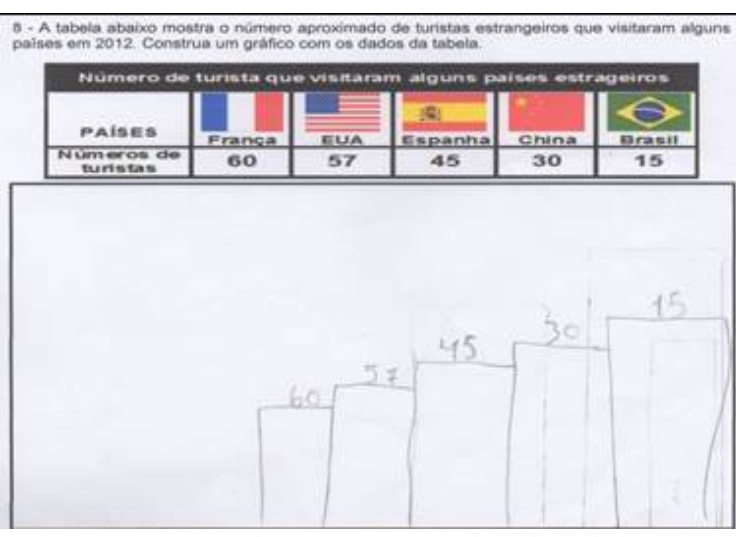

Figure 6: Example of response for the ability to build a graph from a table (question 8).

Our results corroborate the idea that students find it hard to build graphics with correct proportional scales, as noted by Silva (2012) with students in the 3rd and 5th grades of schooling, and Lima (2010) with adult with low education.

In this sense, Evangelista and Guimarães (2013) emphasize the need for textbooks which explore not only interpretation activities, but also scale construction, in order to enable students to develop both skills, since one complements the other.

We also emphasize that the activities worked in the three approaches used in teaching intervention did not lead a group to use a specific type of strategy. It was just found different percentages in different issues worked in the tests. So we cannot be biased toward one approach over the other; rather, we would say that both interventions made learning how to read scales easier.

\section{CONCLUSIONS}

Our results show that before long, regardless the type of activity utilized, one can promote student's learning how to read scales through the different contexts within textbooks. We explored three different situations (measure of length, number of lines and maps) in a teaching intervention and achieved significant progress with the three groups.

Students became unresponsive when the interventions were at random, and they started showing to be highly concerned with the sequence of the magnitude of the numbers, and the proportionality between the spaces was still a difficulty. Still, many students demonstrated to have understood the importance of proportionality expressed on a scale, what made them perform the activities more appropriately, devoting more care in representing, locating, analyzing, comparing and building scales correctly.

In this view, we would like to bring to attention the need for an interrelated and systematic work in school so that an understanding of length, a discussion on measurements of units and subunits be implemented along with the development of an association of scales presented in charts.

Thence, based on the analyses and discussions presented in this article, we believe there is evidence to prove that it is possible to teach 5th grade students in primary school how to read scales. This was evident when we addressed this concept in three teaching situations at different public schools, and we found significant progress in the students' learning capacity.

\section{REFERENCES}

Albuquerque, M.C. (2010). Como adultos e crianças compreendem a escala representada em gráficos. Dissertação (mestrado) - Programa de Pós-graduação em Educação Matemática e tecnológica - Universidade Federal de Pernambuco. CE.

Brasil (1997). Ministério da Educação e Desposto, Secretaria de Educação Fundamental. Parâmetro Curriculares Nacionais de Matemática do Ensino Fundamental I- $1^{a} a \grave{a} 4^{a}$ série. Brasília, DF. 
Bruno, A., \& Espinel, M. C. (2205). Recta numérica, escalas y gráficas estadísticas: un estudio con estudiantes para profesores. Formación del Profesorado e Investigación en Educación Matemática VII, 57-85, 2005.

Cavalcanti, M., Natrielli, K. R. B., \& Guimarães, G. (2010). Gráficos na Mídia Impressa. Bolema, Rio Claro (SP), 23(36), 733 - 751.

Evangelista, M. B \& Guimarães, G. (2013). Analise de atividade de livros didáticos de matemática do $4^{\circ}$ e $5^{\circ}$ ano que exploram o conceito de escala. In: Anais VII Congreso Iberomericano de Educación Matemática - CIBEM. Montevideo.

Guimarães, G. L. (2009). Categorização e representação de dados: o que sabem os alunos do Ensino Fundamental. In: Borba, R.; Guimarães, G. (Orgs.). A pesquisa em educação matemática: repercussões na sala de aula. São Paulo: Cortez.

Guimarães, G. L. (2002). Interpretando e Construindo Gráficos de Barras. Tese (Doutorado em Psicologia Cognitiva). Universidade Federal de Pernambuco, Recife.

Lima, R. C. R. (2005). Introduzindo o conceito de média aritmética na $4^{a}$ série do Ensino Fundamental usando o ambiente computacional. Dissertação (mestrado) - Programa de Pósgraduação em Educação Matemática - Universidade Católica de São Paulo.

Lopes, C. E. (2008). O Ensino da Estatística e da Probabilidade na Educação Básica e na formação dos professores. Cadernos Cedes, Campinas, 28(74), 57-73. Disponível em http://www.cedes.unicamp.br. Acessado em 18/12/2012.

Melo, M. S. \& Bellemain, P. (2004). Ensino e a aprendizagem do conceito de escala, no quarto ciclo do Ensino Fundamental, à luz da teoria dos campos conceituais. In: Anais do VIII Encontro Nacional de Educação Matemática - ENEM. Recife.

Pontes, J. P.; Brocardo, J. \& Oliveira, H. (2009). Investigações matemática na sala de aula. $2^{\mathrm{a}}$ edição. Belo Horizonte: Autêntica.

Silva, D. B. (2012). Analisando a transformação entre gráficos e tabelas por alunos do $3^{\circ}$ e $5^{\circ}$ ano do Ensino Fundamental. Dissertação (mestrado) - Programa de Pós-graduação em Educação Matemática e tecnológica - Universidade Federal de Pernambuco. CE. 